\title{
Pemberdayaan Kelompok Masyarakat Desa Ketapang Raya Melalui Usaha Produktif Terasi Rebon Pasca Gempa Lombok
}

\author{
Siti Nurhidayati ${ }^{\star}$, Khaeruman, Diah Lukitasari \\ Universitas Pendidikan Mandalika, Jl. Pemuda No. 59 A, Mataram, 83125 Indonesia \\ Email Korespondensi: sitinurhidayati328@gmail.com
}

\section{Diterima: April 2020; Revisi: Mei 2020; Diterbitkan: Mei 2020}

\begin{abstract}
Abstrak
Masyarakat Ketapang Raya pada umumnya belum memanfaatkan potensi lokal/sumber daya alam sekitar secara optimal. Kegiatan pengabdian bertujuan untuk membelajarkan keterampilan dalam memilih bahan baku dan cara pembuatan terasi, keterampilan dalam pengawetan terasi tanpa bahan kimia, pengemasan terasi, serta keterampilan memasarkan prosuk yang dihasilkan, sehingga terbentuk usaha produktif terasi rebon melalui penggalaman dengan memaksimalkan sumber daya alam sekitar. Kegiatan ini berbentuk penyuluhan, pelatihan dan pendampingan secara berkala dan berkelanjutan yang dilaksanakan dalam tahapan-tahapan (1) persiapan dan pembekalan, (2) pelaksanaan, (3) analisis kegiatan, dan (4) evaluasi kegiatan. Hasil dari kegiatan ini menunjukkan bahwa potensi tenaga lokal (mitra) dalam mengelola sumber daya local menjadi usaha produktif terasi rebon ditemukan mengalami perkembangan yang baik. Di samping itu, masyarakat terampil dalam memilih bahan baku terasi, terampil dalam proses pembuatan terasi, terampil dalam menggunakan pengawet tanpa bahan kimia, terampil dalam pengeringan dan pengemasan produk (packaging). Berdasarkan hasil kegiatan dapat disimpulkan bahwa, kegiatan pengabdian ini dapat memunculkan potensi tenaga local dalam mengelola sumber daya local dan meningkatkan keterampilan mitra untuk lebih produktif.
\end{abstract}

Kata Kunci: Pemberdayaan Masyarakat; Usaha Produktif; Terasi Rebon

\section{Empowerment of Ketapang Raya Village Community Groups through Productive Efforts of Rebon Paste after the Lombok Earthquake}

\begin{abstract}
The people of Ketapang Raya in general have not optimally utilized the local potential / natural resources around them. The service activity aims to teach skills in choosing raw materials and how to make shrimp paste, skills in preserving shrimp paste without chemicals, packaging shrimp paste, and marketing skills for the resulting products, so that a productive business of rebon shrimp paste is formed through experience by maximizing the surrounding natural resources. This activity takes the form of regular and continuous counseling, training and mentoring carried out in the stages (1) preparation and debriefing, (2) implementation, (3) analysis, and (4) evaluation of activities. The results of this activity indicate that the potential of local workers (partners) in managing local resources to become productive businesses of rebon shrimp paste was found to have experienced good development. In addition, people are skilled in selecting raw materials for shrimp paste, skilled in the process of making shrimp paste, skilled in using preservatives without chemicals, skilled in drying and product packaging (packaging). Based on the results of the activity, it can be concluded that, this service activity can bring out the potential of local workers in managing local resources and improving partners' skills to be more productive.
\end{abstract}

Keywords: Community empowerment; Productive Business; Rebon shrimp paste

How to Cite: Nurhidayati, S., Khaeruman, K., \& Lukitasari, D. (2020). Pemberdayaan Kelompok Masyarakat Desa Ketapang Raya Melalui Usaha Produktif Terasi Rebon Pasca Gempa Lombok. Lumbung Inovasi: Jurnal Pengabdian kepada Masyarakat, 5(1), 1-8. doi:https://doi.org/10.36312/linov.v5i1.458 


\section{PENDAHULUAN}

Desa Ketapang Raya Kecamatan Keruak Kabupaten Lombok Timur termasuk salah satu daerah pesisir di bagian selatan Lombok NTB (Kecarat, 2016). Lombok pernah mengalami musibah gempa bumi dengan skala 7,0 SR disertai gempa susulan yang terus terjadi, disamping itu hasil kajian dari BMKG melalui surat resmi berupa permakluman dengan nomor: GF.102/249KMTR/VII/2019 yang disebarkan tanggal 9 Juli 2019 mempredisikan bahwa akan ada gempa besar dan tsunami yang akan menimpa akibat lempengan indoaustrali yang membentang di laut selatan pulau Lombok (Arnani, 2019).

Hasil kajian tersebut membuat warga pesisir selatan Lombok selalu dihantui rasa cemas dan kurang bersemangat dalam bekerja, hal ini tentunya akan berdampak buruk terhadap sosial-ekonomi masyarakat. Ketapang Raya menghasilkan banyak ikan, rebon (udang kecil) dan garam. Sebagian besar penduduknya berprofesi sebagai nelayan, sebagian lagi berprofesi sebagai petani garam dan buruh pengangkut ikan dari sampan/perahu nelayan yang diupah menggunakan ikan dan rebon. Pendapatannya bergantung pada musim, dimana masyarakat sekitar masih memiliki taraf ekonomi penghasilan rendah (Fadlun, 2019). Desa ini termasuk daerah tertinggal dan merupakan salah satu Daerah Prioritas Nasional.

Di Desa Ketapang Raya ini, masyarakat belum memanfaatkan potensi lokal/sumber daya alam yang melimpah di sekitarnya secara optimal menjadi usaha-usaha yang lebih produktif, padahal pada musimnya nelayan memperoleh banyak ikan dan rebon, petani garam memproduksi banyak garam dari tambak garam, sehingga ikan, rebon dan garam mudah didapat dan harganya sangat murah.

Untuk memulihkan sosial-ekonomi masyarakat pasca gempa, Pemerintah dan berbagai Lembaga berbondong-bondong untuk melakukan trauma healing kepada masyarakat dengan memberikan berbagai macam hiburan dan kegiatan, salah satu diantaranya Lembaga IKIP Mataram yang sekarang telah berubah menjadi Universitas Pendidikan Mandalika (UNDIKMA) Mataram. Dalam kegiatan pengabdian masyarakat ini dikemas dalam bentuk program PKM akan dilakukan trauma healing berupa pemberdayaan pada masyarakat untuk mengisi waktu luang mereka dalam bentuk memberikan penyuluhan, pelatihan dan pendampingan secara berkala dan berkelanjutan kepada masyarakat untuk membentuk usaha-usaha produktif berupa terasi rebon melalui penggaraman. Trauma yang dialami masyarakat penting untuk direduksi untuk meminimalisir dampkak psikologis dan fisik bagi masyarakat yang terdampak bencana (Mulyasih \& Putri, 2019; Sa'i \& Acim, 2018).

Pemanfaatan waktu luang dengan kegiatan-kegiatan produktif tentu mengurangi kecemasan masyarakat terkait berbagai isu gempa dan prediksi tsunami yang berkembang di tengah masyarakat sebagai upaya pemulihan ekonomi masyarakat pasca gempa di bumi Lombok. Melalui kegiatan ini masyarakat dapat mengisi waktu luang dengan memaksimalkan sumber daya alam sekitar (Nurhidayati \& Ariani, 2019) berupa ikan laut, rebon dan garam untuk dijadikan terasi yang merupakan salah satu penyedap makanan yang sangat digemari oleh semua kalangan masyarakat. Daerah Lombok kaya akan makanan tradisional yang hampir semua jenis makanannya ditambahkan terasi, diantaranya: pelecing, sate, rujak, ares, sambel colet, ayam taliwang dan masakan sayur lainnya.

Kegiatan pemberdayaan ini bertujuan untuk membelajarkan keterampilan dalam memilih bahan baku terasi, keterampilan dalam pembuatan terasi, keterampilan dalam penggunaan pengawet tanpa bahan kimia, keterampilan mengemas terasi menggunakan packaging yang menarik dan keterampilan dalam memasarkannya. Selain itu, masyarakat dapat ikut berpartisipasi dalam pemulihan ekonomi masyarakat pasca gempa di pulau Lombok dan memanfaatkan waktu luang secara produktif untuk mereduksi trauma yang tengah dialami.

\section{METODE PELAKSANAAN}

Kegiatan ini berbentuk penyuluhan, pelatihan dan pendampingan secara berkala dan berkelanjutan yang dilaksanakan dalam tahapan-tahapan (1) persiapan dan pembekalan, (2) pelaksanaan, (3) analisis kegiatan, dan (4) evaluasi kegiatan. Secara ringkas alur kegiatan disajikan pada Gambar 1. 


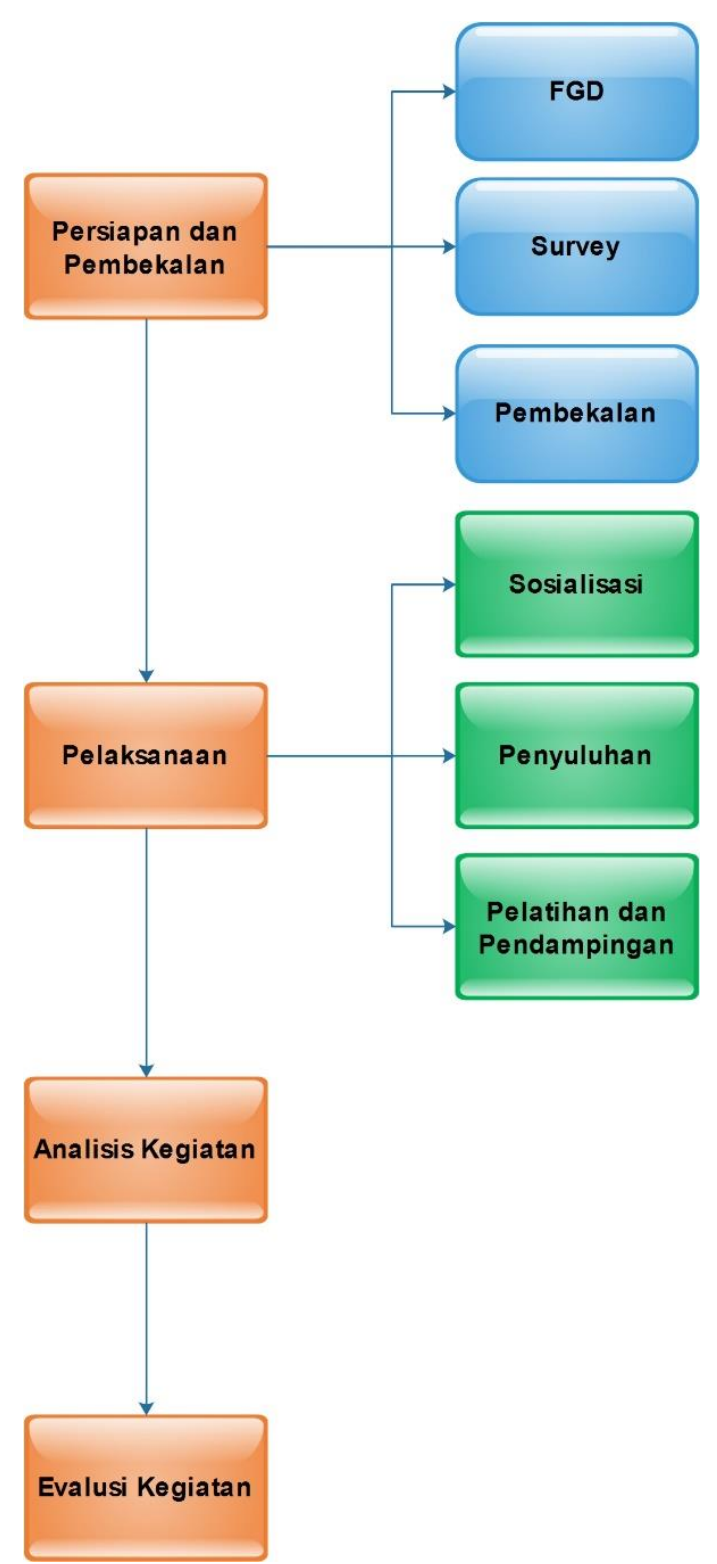

Gambar 1. Alur kegiatan pengabdian kepada masyarakat

\section{HASIL DAN PEMBAHASAN}

Pelaksanaan pengabdian kepada masyarakat dilakukan di desa Ketapang raya kecamatan keruak kabupaten Lombok Timur. Ada beberapa tahapan/kegiatan yang dikakukan diantaranya.

\section{Persiapan dan Pembekalan}

Persiapan yang dilakukan berupa FGD persiapan PKM, survey lokasi yang dilakukan oleh Tim PKM bersama mahasiswa untuk mengetahui bagaimana keadaan lokasi pengabdian, potensi lokal desa, keadaan masyarakat, selain itu dilakukan pembekalan mahasiswa guna menyamakan persepsi antara Tim PKM dan mahasiswa.

\section{Pelaksanaan Program PKM}

Ada beberapa kegiatan yang dilakukan diantaranya.

(a) Gambar 2 menunjukkan kegiatan Sosialisasi Program PKM. Sosialisasi program PKM kepada masyarakat, sehingga masyarakat tidak mengalami kebingungan dengan program yang kami lakukan, tetapi menjadi termotivasi untuk mengikuti berbagai penyuluhan, pelatihan dan pendampingan. Sosialisasi yang dilakukan Tim Pengabdian diantaranya (1) memberikan pengetahuan tentang tujuan program PKM dengan Kepala Desa yang akan diteruskan pada Kepala Dusun, Pemuda dan Tokoh Masyarakat yang 
ada di Desa Ketapang Raya, (2) Merumuskan pola pelaksanaan program penyuluhan, pelatihan dan pendampingan di lapangan.

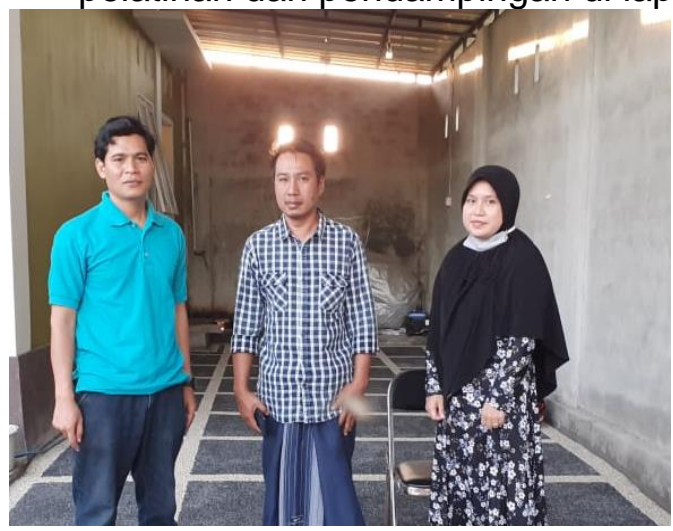

Gambar 2. Sosialisasi Program PKM dengan Kepala Desa Ketapang Raya

(b) Gambar 3 menunjukkan kegiatan penyuluhan dalam pengabdian ini. Penyuluhan dilakukan Tim PKM Undikma untuk meningkatkan pemahaman masyarakat tentang (1) Perlunya memaksimalkan berbagai potensi lokal/sumber daya alam sekitar menjadi usaha-usaha produktif, salah satu contohnya usaha produktif terasi melalui penggaraman, (2) Perlunya memilih bahan baku terasi, (3) Cara-cara pembuatan terasi, (4) Cara pengawetan tanpa menggunakan bahan kimia, (5) Cara pengeringan dan pengemasan terasi menggunakan packaging yang menarik, dan (6) Cara pemasaran terasi.

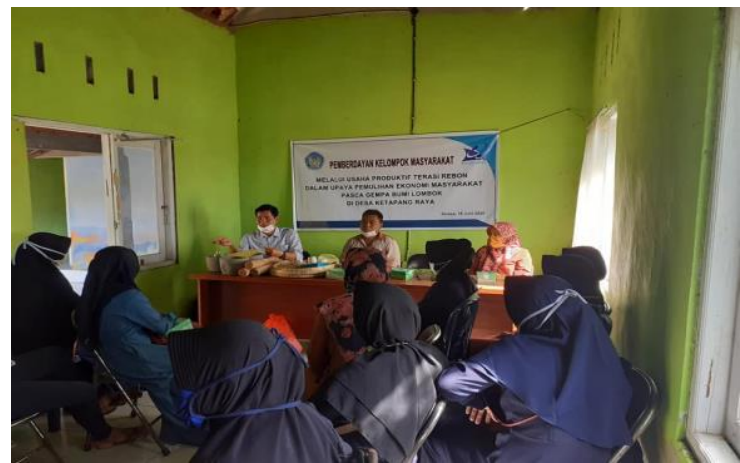

Gambar 3. Penyuluhan Program PKM

Selain penyuluhan, masyarakat juga diberikan berbagai fasilitas berupa alat-alat yang dibutuhkan dalam pembuatan terasi rebon diantaranya, bak pencucian, bak penyaringan, lumpang batu, alu, nampan, timbangan, pengaduk, keleong, pisau, pengaduk, spatula, dan lain-lain seperti ditunjukkan pada Gambar 4.

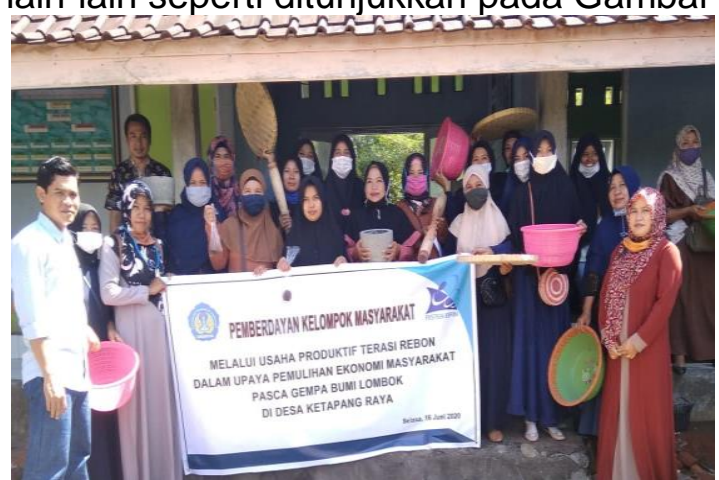

Gambar 4. Simbolis Penyerahan Alat-alat Pembuatan Terasi Rebon

(c) Gambar 5 sampai Gambar 9 menunjukkan kegiatan Pelatihan dan Pendampingan Masyarakat dalam memilih Bahan Baku Terasi dan Pembuatan Terasi Rebon. Pelatihan dan Pendampingan Masyarakat dalam memilih bahan baku terasi dan cara pembuatan terasi rebon dilaksanakan oleh Tim Pengabdian dibantu oleh mahasiswa Undikma. Pemilihan bahan baku berupa pemilihan rebon dan ikan kecil yang segar berdasarkan 
tekstur, warna dan aromanya. Masyarakat sekitar tentu sangat akrab dengan bahan baku berupa rebon, ikan kecil dan garam, bagaimana memilih sesuai dengan tingkat kesegarannya. Yang perlu ditekankan pada masyarakat adalah kualitas bahan baku akan menentukan cita rasa terasi. Menurut (Karim et al., 2014) kualitas bahan baku dalam pembuatan terasi akan menentukan warna dan rasa terasi. Terasi akan terasa lebih nikmat bila dibuat menggunakan udang segar (Bahari, 2015).

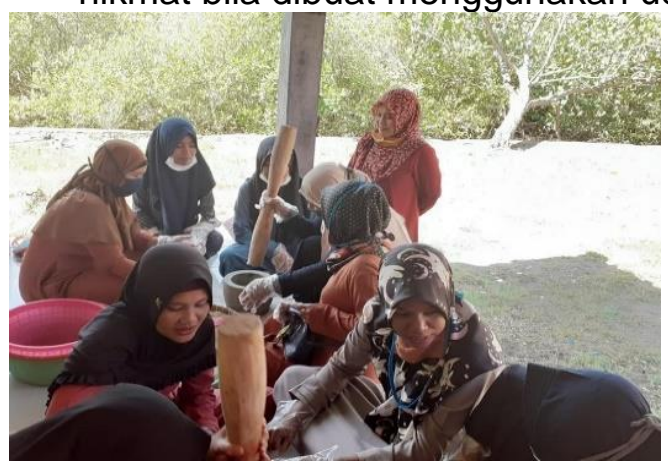

Gambar 5. Pelatihan dan Pendampingan Pembuatan Terasi

Pembuatan terasi rebon dilakukan dengan penggaraman, dengan tahapan sebagai berikut: 1) Mencuci rebon (udang kecil) atau ikan kecil sampai bersih dari kotoran, 2) Meniriskan hingga airnya kering dan jemur hingga udang atau ikan kecil benar-benar kering, 3) Setelah rebon (udang kecil) kering masukkan udang rebon atau ikan kecil-kecil di dalam alat penggiling, tambahkan semua bumbu yang tersedia, 4) Menumbuk hingga halus membentuk sebuah adonan lalu jemur hingga kering, untuk mendapatkan hasil yang lembut dan kualitas yang baik biasanya setelah digiling dijemur kembali, hingga 2 kali penggilingan. Mencetak terasi dan menjemurnya kembali, 5) Membungkus terasi menggunakan packaging yang menarik dan siap untuk dipasarkan (Bahari, 2015). Tahapan proses pembuatan terasi disajikan pada Gambar 6 berikut.
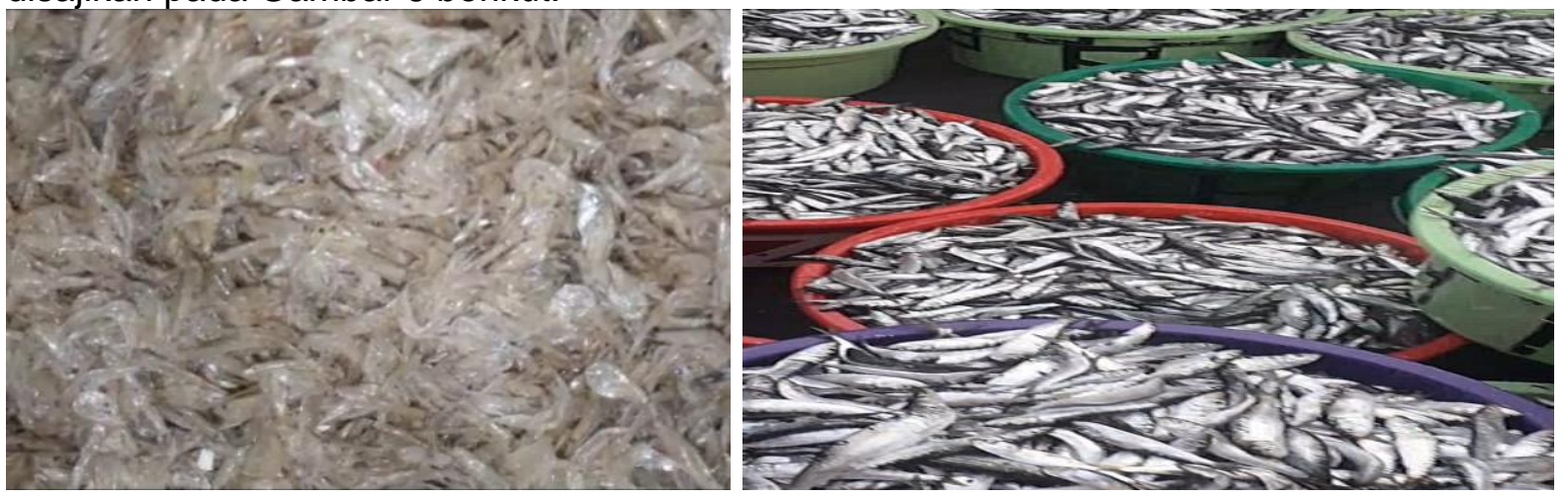

Gambar 6. Udang kecil/rebon basah dan Ikan Kecil Basah
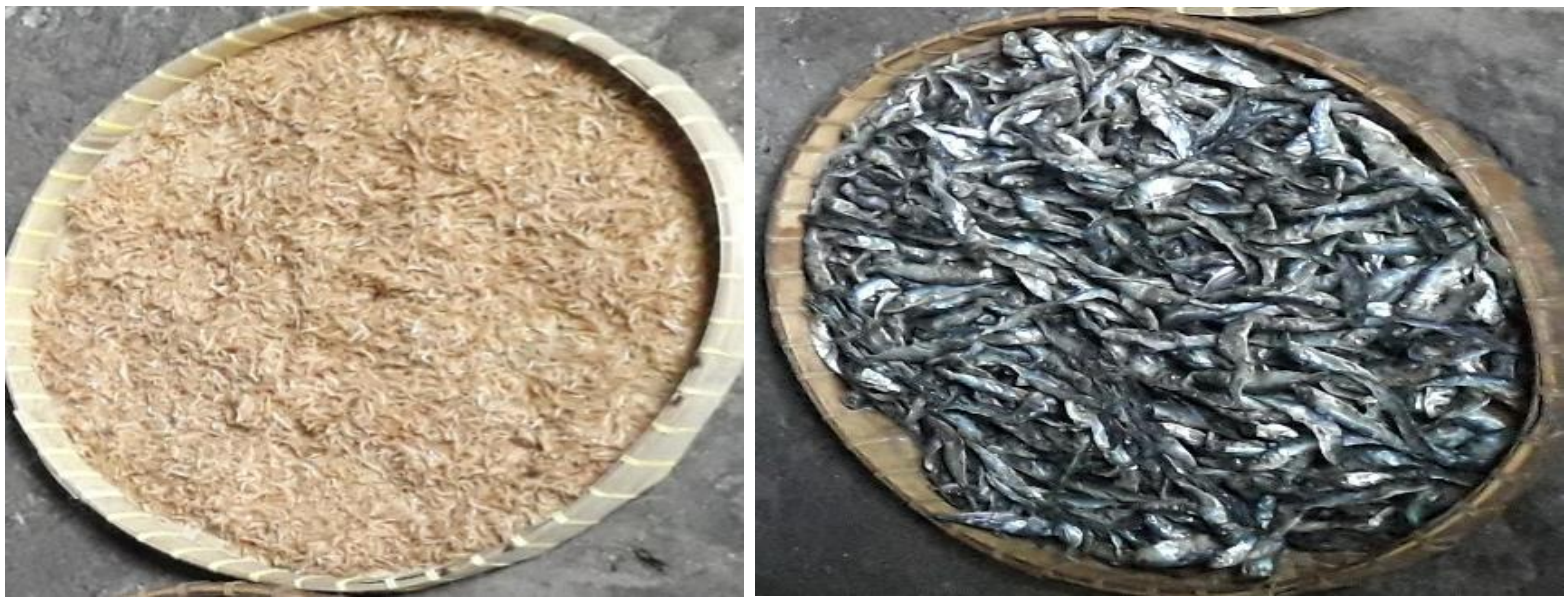

Gambar 7. Udang Kecil/Rebon Kering dan Ikan Kecil Kering 


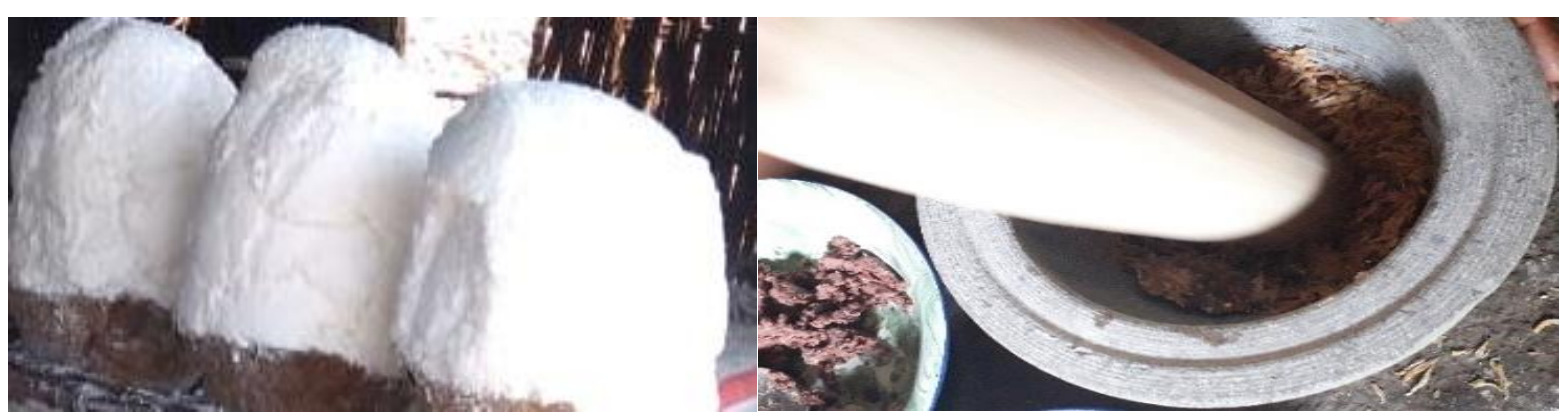

Gambar 8. Garam F dan Proses Penumbukan

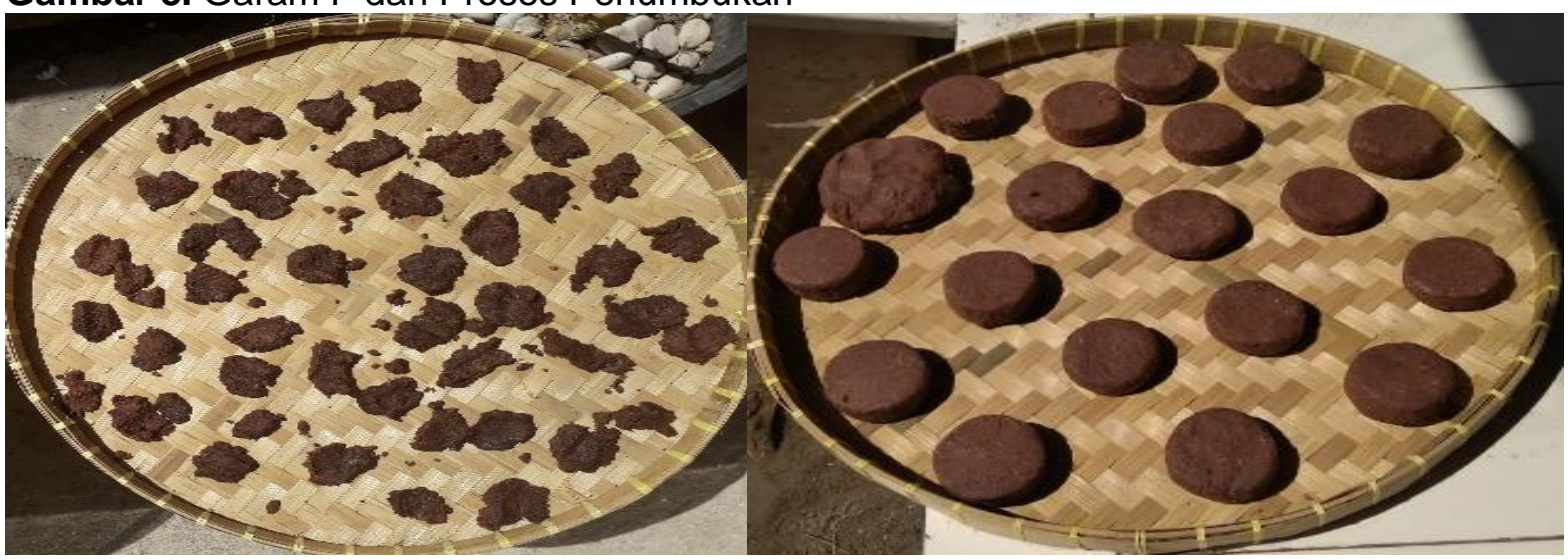

Gambar 9. Pengeringan I dan Pengeringan II

(d) Gambar 10 menunjukkan kegiatan Pelatihan dan pendampingan masyarakat dalam Penggunaan Pengawet Tanpa Bahan Kimia dan Cara Pengeringan Terasi. Pelatihan dan pendampingan masyarakat dalam penggunaan pengawet tanpa bahan kimia dan cara pengeringan terasi dilaksanakan oleh Tim Pengabdian dibantu oleh mahasiswa Undikma. Penggunaan pengawet tanpa bahan kimia tentu membuat produk berupa terasi rebon bertahan lama, akan tetapi tidak berbahaya ketika dikonsumsi oleh masyarakat. Dalam pembuatan terasi rebon, pengawet tanpa bahan kimia yang digunakan adalah garam dengan konsentrasi 20\% atau 2 ons per kg bahan baku terasi rebon (Bahari, 2015). Garam berfungsi sebagai pengawet alami dan dapat memberi rasa pada terasi rebon. Selain digunakan pengawet alami, proses pengeringan juga dilakukan sebanyak dua kali agar terasi dapat bertahan lama. Proses pengeringan juga menentukan kecepatan produksi dan kualitas terasi (Rikah \& Widodo, 2019).

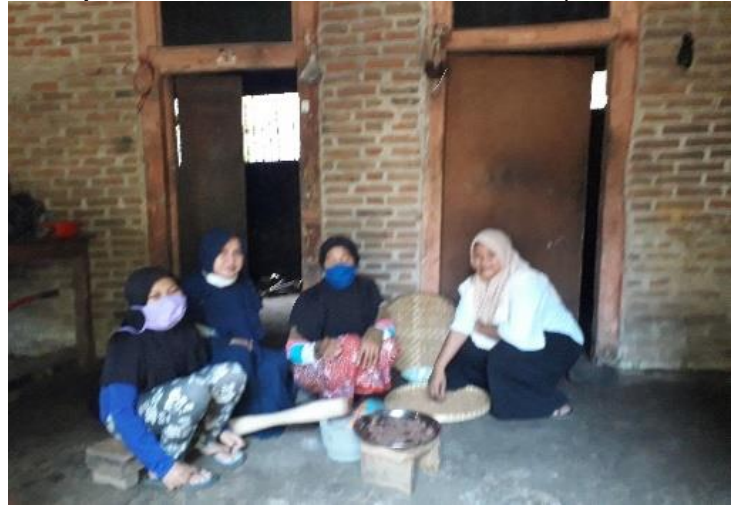

Gambar 10. Pendampingan Program PKM

(e) Gambar 11 menunjukkan kegiatan Pelatihan dan Pendampingan Masyarakat dalam Pengemasan dan Pemasaran Terasi. Pelatihan dan pendampingan masyarakat dalam pemasaran produk (terasi rebon) dilaksanakan oleh Tim Pengabdian dibantu oleh mahasiswa Undikma. Terasi rebon yang sudah cetak dan dikeringkan kemudian dikemas. Pengemasan terasi dilakukan dengan 2 lapisan serta menggunakan packaging yang 
didesain semenarik mungkin agar produk dapat bertahan lama dan mampu menarik minat konsumen, karena pengemasan tradisional cendrung mengurangi minat konsumen (Hidayat \& Mahanani, 2018).

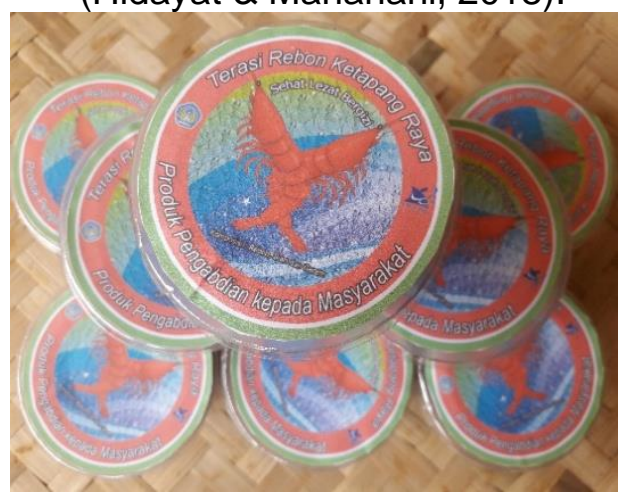

Gambar 11. Produk (Terasi Rebon)

Terasi yang sudah dikemas, siap untuk dipasarkan secara manual, online, didistribusikan ke Pusat Oleh-oleh Khas Lombok atau menggunakan 2 bahasa dalam pemasaran, hal tersebut bergantung pada hasil survey pasar (Ariani \& Nurhidayati, 2019).

\section{Analisis Data}

Data pengabdian yang diperoleh di lapangan perlu dikelompokkan dan dianalisis secara deskriftif. Analisis data pengabdian akan dilakukan secara bersama-sama oleh tim pengabdian. Hasil analisis menunjukkan bahwa potensi tenaga lokal (mitra) dalam mengelola sumber daya local menjadi usaha produktif terasi rebon ditemukan mengalami perkembangan yang baik. Di samping itu, masyarakat terampil dalam memilih bahan baku terasi, terampil dalam proses pembuatan terasi, terampil dalam menggunakan pengawet tanpa bahan kimia, terampil dalam pengeringan dan pengemasan produk (packaging) setelah kegiatan pengabdian ini dilaksanakan.

\section{Evaluasi Program PKM}

Evaluasi program telah dilakukan oleh Tim PKM 1 kali dalam 2 minggu untuk mengetahui bagaimana keberlangsungan dan kemajuan dari kegiatan yang dilakukan, selain itu membahas berbagai masalah dan kendala yang terjadi di lapangan untuk menemukan solusi yang tepat serta melakukan pendampingan terhadap masalah atau kendala di tengah masyarakat selama pelaksanaan program PKM.

\section{KESIMPULAN}

Berdasarkan hasil kegiatan dapat disimpulkan bahwa, kegiatan pengabdian ini dapat memunculkan potensi tenaga local dalam mengelola sumber daya local dan meningkatkan keterampilan mitra untuk lebih produktif.

\section{REKOMENDASI}

Beberapa rekomendasi yang dapat diajukan berdasarkan hasil analisis dan evaluasi kegiatan diantaranya (1) diperlukan berbagai teknologi sederhana untuk meningkatkan kualitas pembuatan terasi dan meningkatkan jumlah produksi, dan (2) berbagai potensi lokal desa perlu dikembangkan secara terus menerus untuk meningkatkan keterampilan masyarakat dalam membangun usaha-usaha produktif di berbagai bidang.

\section{DAFTAR PUSTAKA}

Ariani, S., \& Nurhidayati, S. (2019). Pelatihan E_Marketing Karang Taruna Desa Durian Kecamatan Janapria [Laporan Pengabdian Kepada Masyarakat].

Arnani, M. (2019). Beredar Surat Potensi Gempa Bumi dan Tsunami di Lombok, Ini Penjelasan BMKG Halaman all-Kompas.com. https://nasional.kompas.com/read/2019/07/09/17173731/beredar-surat-potensigempa-bumi-dan-tsunami-di-lombok-ini-penjelasan-bmkg?page=all 
Bahari, K. (2015). Cara membuat terasi udang rebon. https://kimbaharisukolilobaru.blogspot.com/2015/09/cara-membuat-terasi-udangrebon.html

Fadlun, S. (2019). Problematika Masyarakat Nelayan dalam Usaha Menigkatkan Kesejahteraan Keluarga Studi Pada Masyarakat Nelayan di Daerah Pesisir Kecamatan Keruak Lombok Timur. Al IIm Jurnal Ilmu Hukum, 1(No 2), 37-57. https://doi.org/10.1234567/al

Hidayat, T., \& Mahanani, R. S. (2018). Inovasi Teknologi Pengemasan Terasi Udang Puger "Hj. $\quad$ Ariyatun." Prosiding. https://publikasi.polije.ac.id/index.php/prosiding/article/view/1176

Karim, F. A., Swastawati, F., \& Anggo, A. D. (2014). PENGARUH PERBEDAAN BAHAN BAKU TERHADAP KANDUNGAN ASAM GLUTAMAT PADA TERASI. Jurnal Pengolahan dan Bioteknologi Hasil Perikanan, 3(4), 51-58.

Kecarat. (2016). Daftar Nama Desa dan Dusun Di Kecamatan Keruak Kabupaten Lombok Timur. http://www.kecarat.com/2016/08/daftar-nama-desa-dusun-dikecamatan $41 . \mathrm{html}$

Mulyasih, R., \& Putri, L. D. (2019). Trauma Healing Dengan Menggunakan Metode Play Terapy Pada Anak-Anak Terkena Dampak Tsunami Di Kecamatan Sumur Propinsi Banten. Bantenese - Jurnal Pengabdian Masyarakat, 1(1). https://doi.org/10.30656/ps2pm.v1i1.1042

Nurhidayati, S., \& Ariani, S. (2019). Pelatihan Pembuatan Mie Kering dari Ubi Ungu Bagi Ibu PKK Di Desa Durian Kecamatan Janapria [Laporan Pengabdian Kepada Masyarakat].

Rikah, R., \& Widodo, A. (2019). PKM Kelompok Usaha Terasi Desa Bonang Kecamatan Lasem dalam Upaya Menghadapi Permasalahan Cuaca. Journal of Dedicators Community, 3(1), 44-52. https://doi.org/10.34001/jdc.v3i1.792

Sa'i, M., \& Acim, S. A. (2018). Trauma healing bagi masyarakat terdampak gempa Desa Gumantar Kecamatan Kayangan Lombok Utara. TRANSFORMASI: Jurnal Pengabdian Masyarakat, 14(1), 1-12. https://doi.org/10.20414/transformasi.v14i1.570 